\title{
On the Strategies of Strengthening the Construction of Campus Culture in Colleges and Universities from the Perspective of the New Era
}

\author{
Yingli Lu \\ Shandong Polytechnic, Jinan 250000, Shandong, China
}

\begin{abstract}
At present, our country has entered a new stage of development. In the context of rapid economic development, people have increasingly realized the importance of cultural construction to social development. As a base for training talents, colleges and universities must fully realize the importance of school culture construction, and combine their own advantages and characteristics to explore effective ways of campus culture construction. Colleges and universities should guide students to establish a correct outlook on life and values, strengthen students' ideological and moral education, promote the construction of a harmonious campus, and promote the connotative development of the school. This article first analyzes the significance of the construction of campus culture in colleges and universities in the new era, and discusses the strategy of constructing campus culture in colleges and universities, hoping to provide some reference for the comprehensive development of college campus culture construction.
\end{abstract}

Keywords: New era, Colleges and universities, Campus culture construction.

\section{Introduction}

College campus culture is the driving force to enhance the core competitiveness and characteristic development of colleges and universities, an important way to implement the fundamental task of fostering virtue through education in colleges and universities, and it is an important measure to realize the comprehensive development of college students' personal qualities and ideological and moral qualities. Especially in the current rapid economic and social development in our country, due to the influence of certain bad habits, higher education is facing many problems such as utilitarianism and marketization, which severely restrict the development of contemporary college students' moral standards and cultural literacy. The existence of these problems is not only a problem of the development of universities themselves, but also a problem of social development. For colleges and universities, in the new era, they should take the construction of campus culture as an entry point, combine their own advantages and various advantageous resources, summarize the problems of their own cultural construction, and build a campus cultural development path with distinctive characteristics of the times. This is the foundation and guarantee for the healthy development of universities.

\section{The Connotation and Significance of the Construction of Campus Culture in Colleges and Universities in the New Era}

\subsection{The Connotation of Campus Culture Construction in Colleges and Universities}

The 18th National Congress of the Communist Party of China put forward the fundamental task of fostering virtue through education. The 19th National Congress of the Communist Party of China proposed to implement the fundamental task of "fostering virtue through education" in education. The 2020 government work report once again emphasized the important significance of the fundamental task of universities and colleges to insist on "fostering virtue through education". The implementation of the fundamental task of "fostering virtue through education" in colleges and universities, improving the ideological and moral standards of contemporary college students, and realizing the connotative development of colleges and universities are inseparable from the construction of college campus culture.

The construction of college campus culture and the development of social culture are closely related. It is necessary to extend and expand on the basis of social and cultural cognition, and combine the university's own characteristics of running a school, long-term educational practice, the school's development history, campus environment and atmosphere and other comprehensive factors to form a socially recognized and widely recognized by the school's teachers and students. A recognized, innovative and distinctive culture.

From the definition of college campus culture, we can know that college campus culture is both universal and particular. The universality is embodied in that it is based on social culture, which means that campus culture cannot be separated from the public's cognition of culture. The particularity lies in the particularity and limitation of the campus culture group and the characteristics of the university itself. Therefore, college campus culture embodies the college's school-running philosophy, school-running characteristics, talent training ideas, campus environment, and the spiritual outlook of the teachers and students in the school[1].

Therefore, if colleges and universities want to develop in a healthy and orderly manner, they must vigorously promote, inherit and innovate campus culture with their own characteristics, and this construction process is what we call the construction of campus culture. In other words, the construction of campus culture is to guide teachers and students in school to spontaneously, plan and purposefully carry out high-quality cultural activities with the 
characteristics of the times and campus characteristics. In this way, it can attract more college students to actively participate in it, and be able to carry out ideological and moral education in the course of the activity, and realize the overall improvement of ideological morality and cultural literacy. At the same time, the construction of campus culture is also a powerful practice to promote the development of universities and realize the task of fostering virtue through education in universities.

\subsection{The Significance of Campus Culture Construction in Colleges and Universities}

As a base for talent training, colleges and universities not only undertake the task of imparting knowledge, but also incorporate educational concepts and practices such as moral education, value guidance, and mental health training into talent training. Good campus cultural activities not only provide necessary spiritual guidance for the growth of teachers and students, but also fully demonstrate the meaning and connotation of higher education. Not only that, the rich cultural activities not only enrich the campus life of teachers and students, but also integrate the traditional culture of the Chinese nation, so that the excellent traditional culture of the Chinese nation has been promoted and passed on. This helps to arouse college students' inner sense of social responsibility, and enable them to form a correct outlook on life, world outlook and values, so as to realize the common improvement of college students' cultural literacy and spiritual civilization. The construction of campus culture in colleges and universities injects vitality into the development of colleges and universities, and brings infinite vitality to the prosperity of the country and the revitalization of the nation[2].

\section{Strategies for the Construction of Campus Culture in Colleges and Universities from the Perspective of the New Era}

\subsection{Guided by the Socialist Core Values, Improve College Students' Understanding of Construction of Campus Culture}

In order to further strengthen the construction of college campus culture and guide college teachers and students to actively participate in the construction of campus culture, we must first improve teachers and students' understanding and understanding of campus culture, and clarify the role of campus culture in promoting college students' values, ideology and morality, and the role of ideological and political education in colleges and universities. Second, it is necessary to change the understanding of university teachers and students on campus culture construction. Guided by the core values of socialism, the campus environment is optimized and the colorful campus cultural activities are used to stimulate students' interest in participating in activities. In the course of the activity, students' self-confidence is cultivated, so that students form a sense of dependence and honor on universities, society, and the country, and subtly influence the formation of students' world outlook, outlook on life and values. At the same time, let campus culture promote the improvement of college students' comprehensive literacy, and promote the long-term, sustainable, and connotative development of colleges and universities.

3.2 Give Full Play to the School's Own Advantages and Build a Characteristic Campus Material Culture

The construction of college campus culture should be based on campus material culture. The beautiful campus environment, complete cultural facilities, and powerful publicity channels not only provide a good learning environment for teachers and students, but also penetrate campus culture into every corner of the university. This is helpful to realize the purpose of integrating and infiltrating campus culture with students' daily study and life, and finally realize the transformation and promotion from campus material culture to spiritual culture. For colleges and universities, the construction of campus material culture can not only stop at the level of environment and infrastructure construction, but also pay attention to the integration of humanistic literacy and campus environment. It is necessary to seek creative and connotative development of material culture on the basis of adhering to the traditional practical and durable construction ideas. For example, the placement of all kinds of sculptures, iconic buildings and warning signs in the campus must be able to convey the connotation of educational ideas, the school's school spirit and motto, not just through intuitive and blunt publicity methods such as slogans and banners. . In addition, the construction of campus material culture needs to combine the school's own advantages. It is necessary to pay attention to campus traditional culture and to be innovative. The construction of campus material culture should integrate elements such as the ideas of the new era and the core values of socialism, while taking into account the overall architectural style and characteristics of the campus, so as to create a campus material and cultural environment with a unified style, distinctive features and prominent connotations[3].

\subsection{Carry out New Campus Cultural Activities}

Colorful campus cultural activities are the best way to promote campus culture. Especially at this stage, the current college students living under the leadership of the party have grown up in a honeypot, lack the ability to distinguish, and are easily affected by bad social trends. How to guide them to form correct values and improve their ideological awareness and state is inseparable from healthy, rich and vivid campus cultural activities. Therefore, campus cultural activities should not only stay at the superficial level of entertainment, but should incorporate diversified elements. Both the form of activity and the content of the program must be diverse and meaningful. For example, speech contests that penetrate the revolutionary traditions of the older generation or traditional Chinese culture, debate contests focusing on popular social topics, and so on. These activities can build a cultural education platform for students, and show the core values of socialism, traditional cultural elements and other humanistic elements and culture in front of students. This will help stimulate students' sense of pride and patriotism, help them build national self-confidence, strengthen their political stand, understand their sense of mission, and build a good campus cultural atmosphere. 


\section{Conclusion}

In a word, under the background of the new era, the fundamental task of colleges and universities to achieve "fostering virtue through education" is to strengthen the construction of campus culture, help students establish a good ideological and moral consciousness, and cultivate the humanistic quality and cultural connotation of college students, so as to contribute to the construction of my country's cultural power and promote the prosperity of socialist cultural development.

\section{References}

[1] Dai Yanhong. Research on the content and countermeasures of campus culture construction in colleges and universities in the new era-Taking Changjiang Engineering Vocational and Technical College as an example[J]. Science Education Journal, 2020, (29): 27-28.

[2] Liu Haizhao, Hao Zixu, Wang Leran, et al. Reflections on the integration of Chinese excellent traditional culture into the construction of college campus culture under the background of the new era[J]. Think Tank Times, 2019, (23): 69-70.

[3] Xing Ruijuan. The path choice of leading the construction of campus culture in colleges and universities with socialist core values in the new era[J]. Journal of Social Sciences of Jiamusi University, 2019, 37(6): 53-56.

[4] Wang Junhao, Su Min. Analysis on the leading path of second classroom thought in colleges and universities $[\mathrm{J}]$. Youth Years, 2018, (34): 54.

[5] Wang Shuiping, Zhang Fan. Research on the cultivation mode of computer innovative talents under the background of "Internet+"'J]. Computer Knowledge and Technology, 2018, 14(35): 144-145,149. 